\title{
Improvement of Maximum Power Point Tracking Perturb and Observe Algorithm for a Standalone Solar Photovoltaic System
}

\author{
MUHAMMAD MATEEN AFZAL AWAN*, AND FAHIM GOHAR AWAN** \\ RECEIVED ON 18.03.2016 ACCEPTED ON 11.05.2016 \\ ABSTRACT
}

\begin{abstract}
Extraction of maximum power from PV (Photovoltaic) cell is necessary to make the PV system efficient. Maximum power can be achieved by operating the system at MPP (Maximum Power Point) (taking the operating point of PV panel to MPP) and for this purpose MPPT (Maximum Power Point Trackers) are used. There are many tracking algorithms/methods used by these trackers which includes incremental conductance, constant voltage method, constant current method, short circuit current method, PAO (Perturb and Observe) method, and open circuit voltage method but PAO is the mostly used algorithm because it is simple and easy to implement. PAO algorithm has some drawbacks, one is low tracking speed under rapid changing weather conditions and second is oscillations of PV systems operating point around MPP. Little improvement is achieved in past papers regarding these issues. In this paper, a new method named "Decrease and Fix" method is successfully introduced as improvement in PAO algorithm to overcome these issues of tracking speed and oscillations. Decrease and fix method is the first successful attempt with PAO algorithm for stability achievement and speeding up of tracking process in photovoltaic system. Complete standalone photovoltaic system's model with improved perturb and observe algorithm is simulated in MATLAB Simulink.
\end{abstract}

Key Words: Photovoltaic Cell, Maximum Power Point Tracking, Perturb and Observe Algorithm, Decrease and Fix Method.

\section{INTRODUCTION}

$\mathrm{P}$ $\mathrm{V}$ is the fastest growing renewable technology of producing energy in the current world because of its priceless benefits like its abundance, environment friendly, cheap maintenance, pollution free (noise and toxic gases), simplicity and easy implementation $[1,2]$. But this growing technology has some serious problems of efficiency from manufacturing materials, change of illumination and temperature. The problem of manufacturing material has been overcome to some extent by using different materials, and $46 \%$ efficiency has been achieved in December 2014 by Japanese AIST (National Institute of Advance Industrial Science and Technology) [3]. Solar PV cell are made up of semiconductor material, mostly with silicon. Semiconductor materials used other than silicon are CdTe (Cadmium Telluride), GaAs (Gallium Arsenide) and CIGS (Copper Indium Gallium Selenide) etc. All these semiconductor materials have a property known as

* Centre of Energy Research \& Development, University of Engineering \& Technology, Lahore.

** Department of Electrical Engineering, University of Engineering \& Technology, Lahore.

Mehran University Research Journal of Engineering \& Technology, Volume 36, No. 3, July, 2017 [p-ISSN: 0254-7821, e-ISSN: 2413-7219] 
photoelectric effect, when exposed to sun light it generates or releases electrons from its conduction band by absorbing the photons of sunlight. These free electrons of PV cell are then captured results an electric current. So, in short "PV cell use solar above bandgap photons as a power source and converts these above bandgap photons directly into electrical energy when exposed to sun light" [4]. These PV cells are connected in the desired order to form modules and arrays. Several PV cells are connected to each other in series to form a PV module and several PV modules are connected to form a PV array. PV modules and arrays are connected in a specific order to get the required output voltage and output current. PV cell generate a DC voltage and can feed dc-loads directly and ac-loads by using inverter before the load, and can also be connected to grid by using conversion devices. To understand the concept of PV cell it can be drawn electronically as shown in Fig. 1 [5].

$\mathrm{I}_{\mathrm{ph}}=\mathrm{Id}+\mathrm{I}_{\mathrm{sh}}+\mathrm{I}_{\mathrm{s}}$

Where $\mathrm{I}_{\mathrm{ph}}$ is Photon Current, $\mathrm{I}_{\mathrm{d}}$ is Diode Current, $\mathrm{I}_{\mathrm{s}}$ is Shunt Current, and $\mathrm{I}_{\mathrm{s}}$ is Output Current.

PV cell presents nonlinear V-I characteristics with one/ single point where power production from $\mathrm{PV}$ cell/panel is maximum and that single point is known as MPP [6-9]. A typical V-I (Voltage-Current) and P-V (Power-Voltage) curves of PV cell with MPP are in shown in Fig. 2. V-I characteristics curve represents with brown color in Fig.

2. The blue line in Fig. 2 represents a power curve.

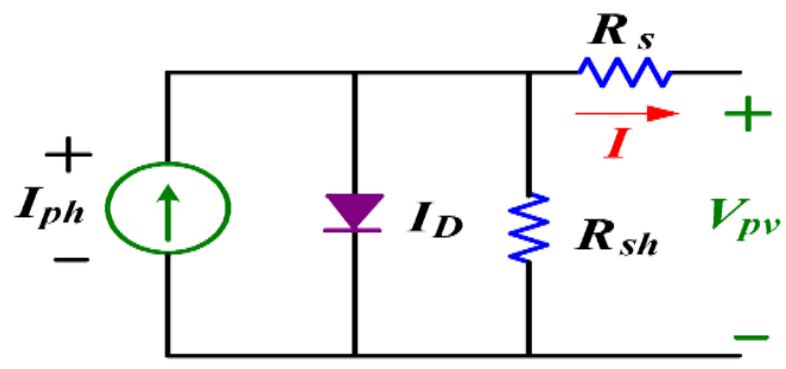

FIG. 1. ELECTRONIC DRAWN EQUIVALENT CIRCUIT OF $P V$ CELL
The maximum power is calculated using Equation (2).

$\mathrm{P}_{\max }=\mathrm{U}_{\mathrm{mpp}} \times \mathrm{I}_{\mathrm{mpp}}$

Where $\mathrm{I}_{\mathrm{sc}}$ is current when circuit is short, $\mathrm{I}_{\mathrm{mpp}}$ is maximum possible current, $\mathrm{U}_{\mathrm{mpp}}$ is maximum possible voltage, and $\mathrm{U}_{\mathrm{oc}}$ is voltage when circuit is open.

The solar PV cell do not deliver maximum power to the user which results in costly (large PV panel is required) and low efficient PV system. To extract maximum power from PV cell it is necessary that PV system should operate at MPP. This MPPs location vary with illumination and temperature [10-12]. Normally the PV system's operating point is at a distance from MPP, so to take the operating power point of PV system to MPP first it is necessary to track this MPP, and for this purpose MPPT are used.

MPPT is an electrical/electronic circuit used to change reference values of the PV array's output voltage or current according to atmospheric conditions so that the system operates with maximum power all the times [13]. MPPT tracks by using an algorithm. Several algorithms have been used like PAO, constant voltage, constant current, incremental conductance and many others. The most commonly used algorithm is PAO because it is simple and easy to implement.

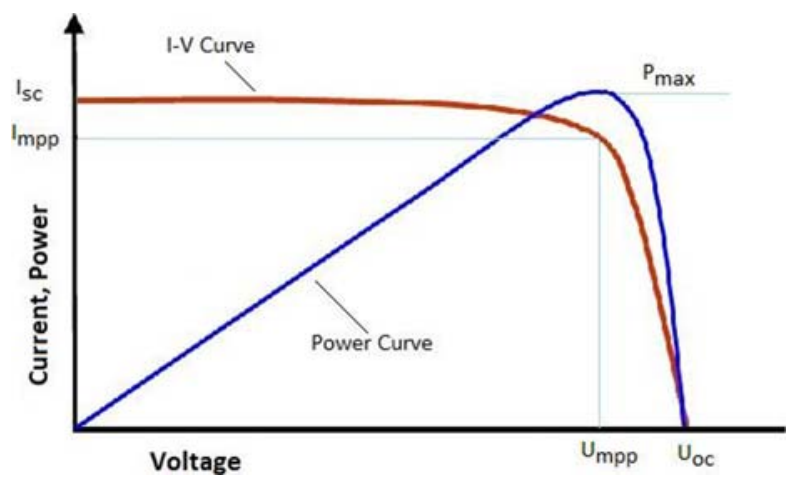

FIG. 2. V-I AND P-V CURVES OF SOLAR PHOTOVOLTAIC CELL

Mehran University Research Journal of Engineering \& Technology, Volume 36, No. 3, July, 2017 [p-ISSN: 0254-7821, e-ISSN: 2413-7219] 
Here the algorithm selected is PAO algorithm but this algorithm has two main problems. One is slow tracking speed during rapidly changing weather conditions and the other is its oscillations around MPP. Several methods have been used to overcome these two problems like using variable step size which improves the performance but only to a limited extent. Slow tracking speed problem is removed to some extent but problem of oscillations around MPP is still there but with less margin.

In this paper, "decrease and fix" method is introduced to overcome these two problems completely and to achieve higher efficiency. Decrease and fix method is the first successful attempt with PAO algorithm for stability achievement and improvement of tracking speed in PV system. This method or technique uses the information of voltage, current and power in a proper manner which lets it know the reason of change in power. With the help of this information the tracker fix the power at a value very close to MPP by stopping the perturbation of voltage. No further perturbation will be made until there is a change in illumination and/ or temperature.

\section{PERTURB AND OBSERVE ALGORITHM}

In PAO algorithm, operating voltage of PV cell/array is perturbed with increment, and resulting change in power is measured and saved as comparative value in algorithm. If a positive change in power occurs, then perturbation continues in the same direction until the PV array's operating point become closer or equal to the MPP. On the next perturbations change in power will be negative (power decreases), indicating that system's operating point is moving away/far from MPP. Then the direction of the perturbation should be reversed to move the operating point back toward the MPP [14] and when operating point crosses MPP with negative perturbation again the perturbation direction turns to positive and then operating point starts oscillations around the MPP. Perturbation is performed by changing the duty cycle of DC-DC buck or boost converter. Duty cycle is defined as the ratio of conduction time to total switching period. PAO algorithm sets the duty cycle of the DC-DC converter according to the need. Adjustment of this duty cycle of DC-DC converter allows to match the load and source impedance of solar PV system to transfer maximum power from source to load [15]. Conventional flow of PAO and observe algorithm is shown in Fig. 3.

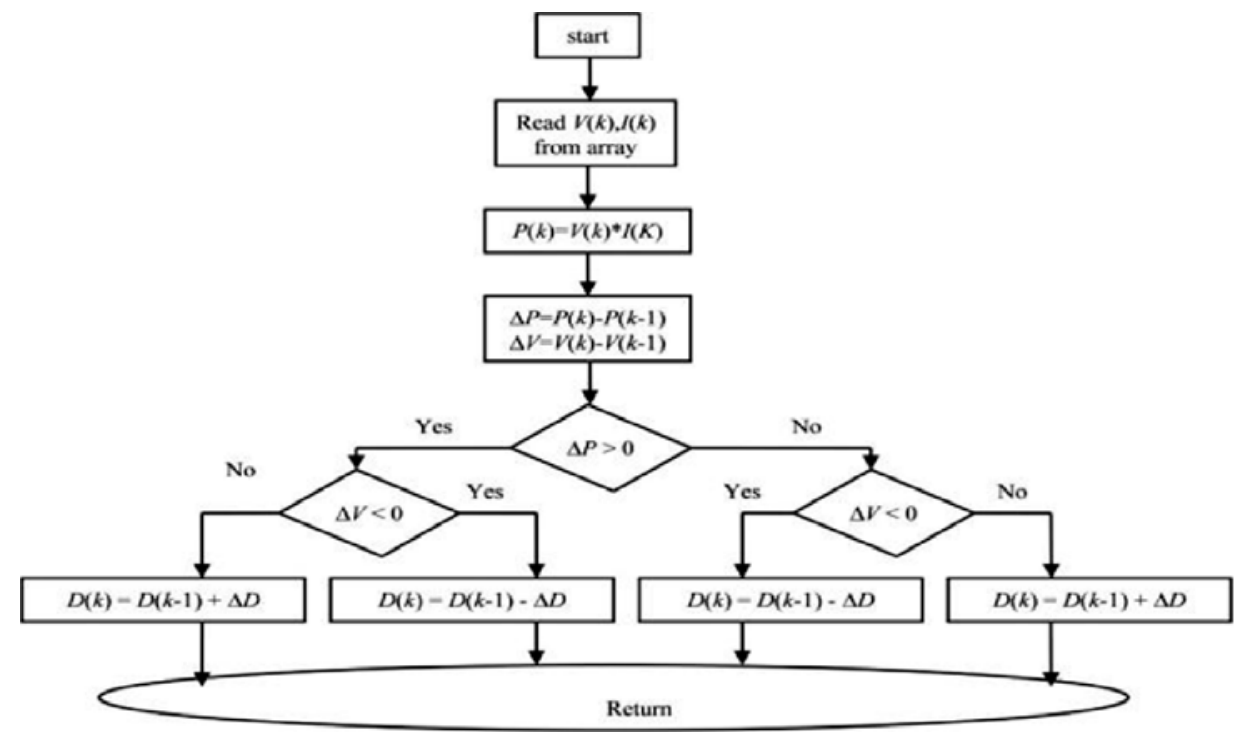

FIG. 3. CONVENTIONAL PERTURB AND OBSERVE ALGORITHM [5] 
This PAO algorithm is a popular method but also have some drawbacks. Oscillations around the MPP and slow tracking speed during rapidly changing weather conditions are the two drawbacks [16]. These drawbacks results in high energy losses. Several methods have been used to overcome these problems [16-17] like using variable step size which improves the performance but not significantly [18]. Both slow tracking speed problem and problem of oscillations around MPP were overcome to some extent by using variable step size PAO algorithm.

\section{PROPOSED METHOD}

Variable step size technique used in PAO algorithm has fast response in tracking MPP but main problem of oscillations of operating point around MPP is still there. Till now in PAO algorithm only one variable's value out of two (voltage or current) is perturbed and results are observed to proceed. This single variable checking creates problem that tracker could not recognize whether the change in power is due to perturbation or due to change in weather condition (illumination or temperature). The reason for this problem of tracking is that operating point is continuously in oscillatory state.

To overcome this problem PAO algorithm is modified by using a "decrease and fix" method. In this method both variable's values (voltage and current) are used to let the tracker know, that the change occurred in power is due to perturbation or due to change in weather conditions (illumination or temperature). The variable step size technique is replaced with "decrease and fix" technique. Fig. 4 shows the flowchart of the proposed algorithm. In this new technique "fix change in stepsize" is introduced instead of variable change in step size. The perturbation of voltage is started with positive sign and large step size until MPP reaches (which speed up the tracking) and divide the step size with two (2) for its first negative perturbation (negative sign) (this boosted the tracking speed because if step size is reduced slowly with voltage change as in conventional PAO algorithm then tracking speed will be slow) and with 4 for its second negative perturbation (again boost is provided to tracking speed) which takes the operating point at MPP or close to MPP because the step size is very small. When the negative perturbation condition goes wrong for first time the perturbation of voltage is stopped (change in duty cycle $=0$, if no change in weather condition which make change in the power delivered by solar PV array) and the PV array will produce stable output voltage without any oscillations.

Two conditions are set for detecting a change in weather condition, first is that when the PV system becomes stable for first time no perturbation will be made until there is a change detected in illumination or temperature (Change in weather condition is detected by change in power without any perturbation) and the second condition is, that during the tracking process when the negative perturbation condition goes wrong for first time then the perturbation of voltage is stopped but with a condition that the algorithm first check that the change in current is positive or negative. If it is positive, it indicates that the change in current occurs due to last perturbation because in the last perturbation voltage was decreased so the current must increase. But if change in current is negative the perturbation continues with positive sign because this indicates the change in weather condition (decrease in illumination or temperature).

\section{SIMULATION TESTS AND RESULTS}

A model of standalone PV system is developed in MATLAB/Simulink. Simulink model and results at STC (Standard Test Condition), $\left(1000 \mathrm{w} / \mathrm{m}^{2}\right.$ and $25^{\circ} \mathrm{C}$ ) are shown in Figs. 5 6. The model contain a PV panel (100-kW PV Array, SunPower SPR-305E-WHT-D (Nser=5 Npar=66)), MPPT, boost converter and resistive load. MPPT 
controller has four inputs (MPPT parameters, Enable, Voltage and Current) and one output (Duty cycle). The voltage acquires stability in $0.35 \mathrm{~s}$ at 271.26 volt sat standard test condition as shown in Fig. 6. Complete output of solar PV array with changing illuminations and changing temperatures is shown in Fig. 7. Output for different illuminations, temperatures and loads are described in Tables 1-2.
In Table $1 \mathrm{PV}$ panel's voltages, currents and powers is shown for different weather conditions (different illuminations and temperatures) at different loads to better understand the performance of PV panel with proposed algorithm. In Table 2 PV panel's voltage, DC-DC converter's output voltages and current is shown for different weather conditions (different illuminations and temperatures) at different loads.

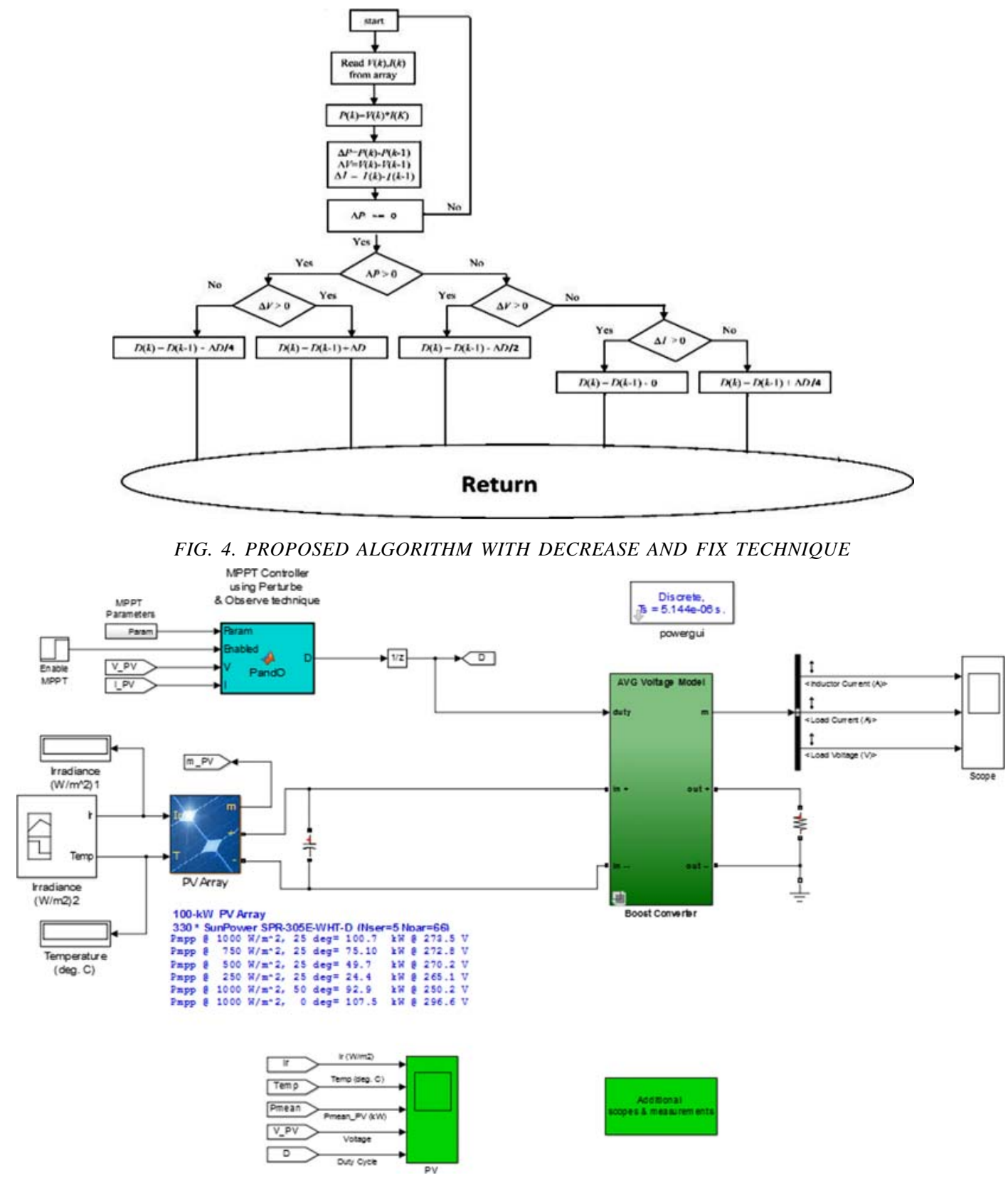

FIG. 5. SIMULINK MODEL OF SOLAR PHOTOVOLTAIC SYSTEM 
It is observed in Tables 1-2that the values of PV panel's voltage and current changes with the change in load connected at the output of DC-DC converter for same illumination and temperature. When the load increases PV panel's voltage will increase and current will decrease and vice versa [19]. So, this improved algorithm is checked for four different loads with different DC-DC converter conversion values. It is observed that high the load connected at output of DC-DC converter higher the DC-DC converter's stepped up output voltage and lower the output current and vice versa, to get maximum power from a PV system at the standard test condition $\left(1000 \mathrm{w} / \mathrm{m}^{2}, 25^{\circ} \mathrm{C}\right)$, for different loads.

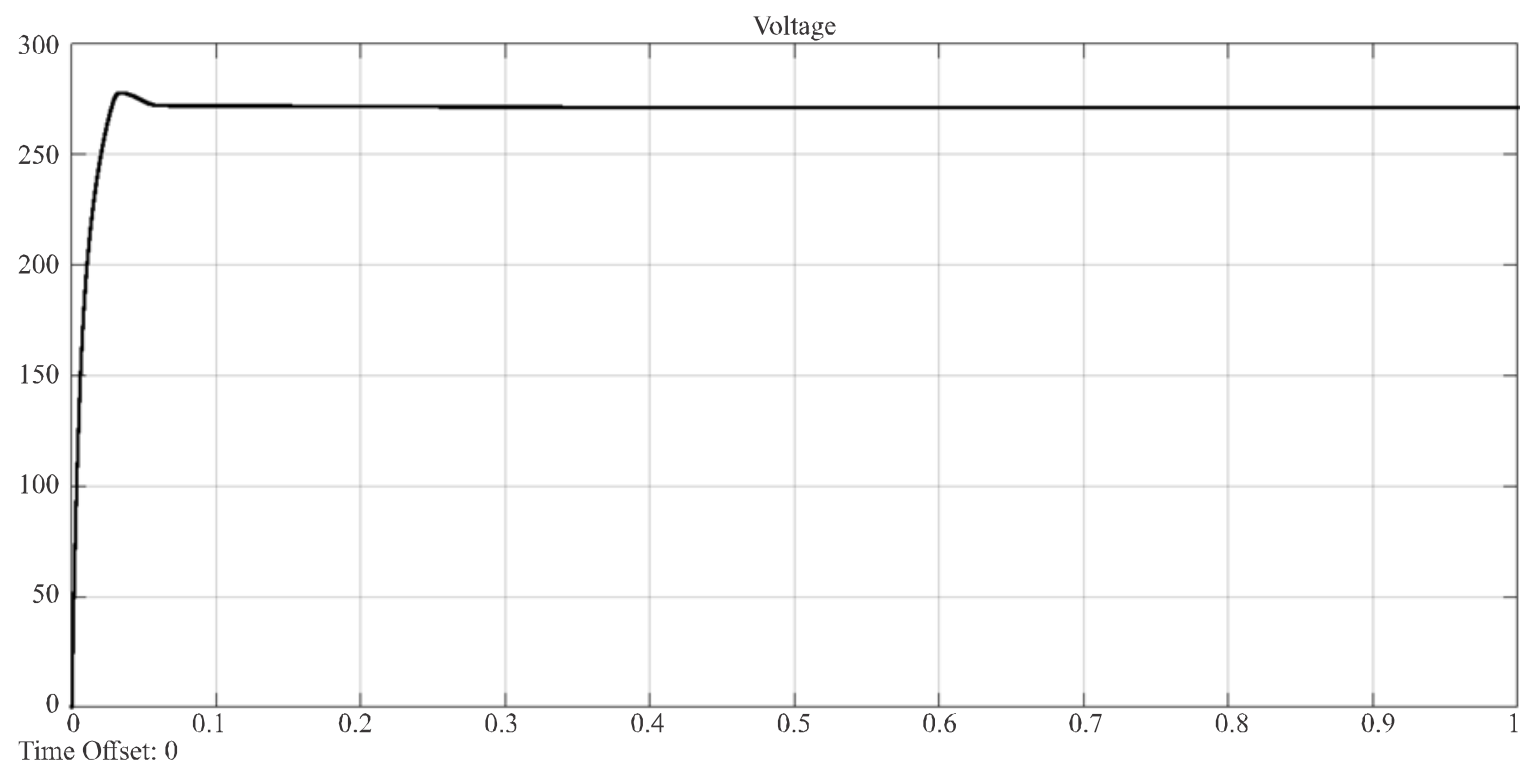

FIG. 6. O/P OF PV ARRAY WITH IMPROVED PAO ALGORITHM AT STC (1000W/M $\left.\mathrm{M}^{2}-25^{\circ} \mathrm{C}\right)$
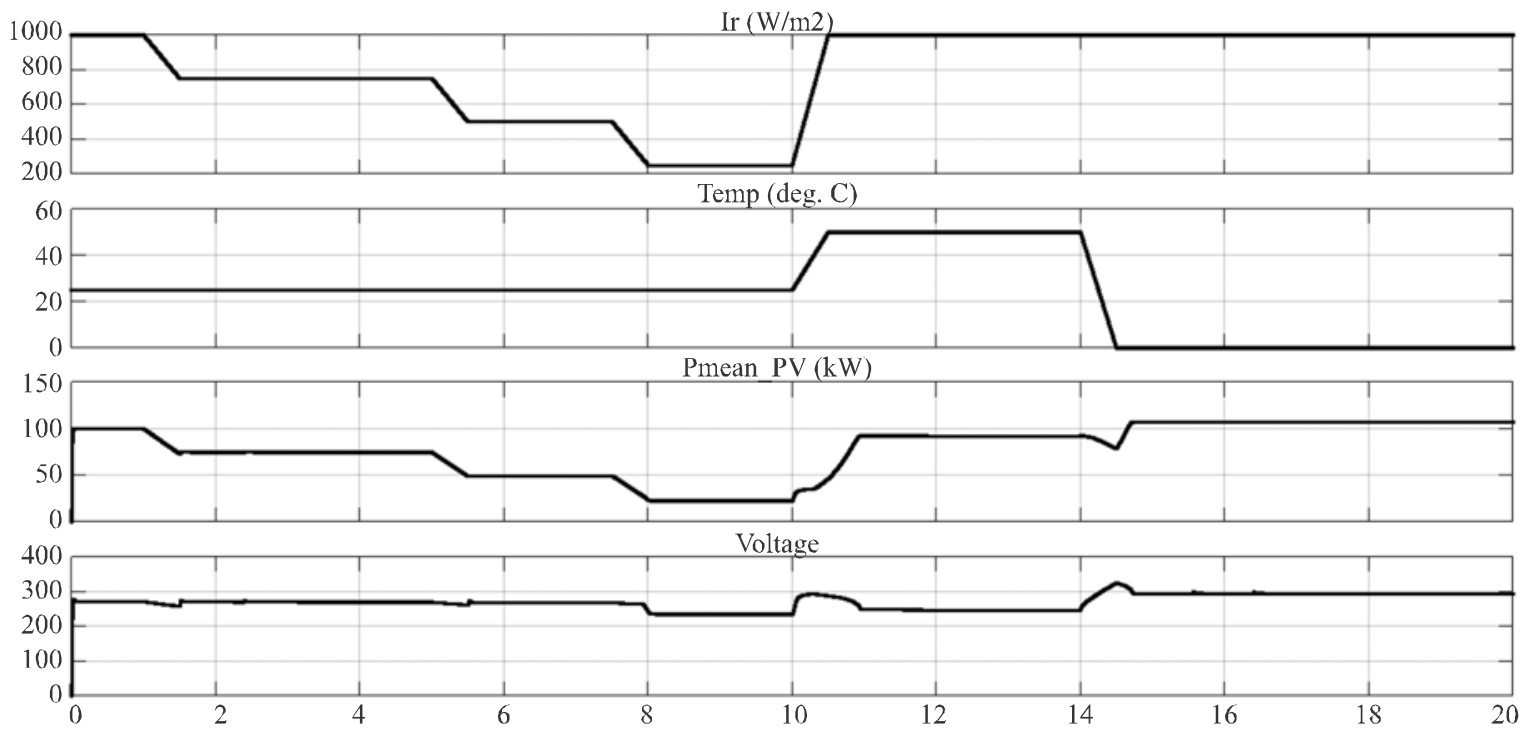

Time Offset: 0

FIG. 7. O/P OF PV ARRAY AT CHANGING WEATHER (1000-250W/M²) $\left(0-50^{\circ} \mathrm{C}\right)$

Mehran University Research Journal of Engineering \& Technology, Volume 36, No. 3, July, 2017 [p-ISSN: 0254-7821, e-ISSN: 2413-7219] 
In the first two conditions of Tables 1-2 zero current is generated from the PV cell because illumination is absent. If illumination is zero, then temperature doesn't matter because generation of current directly depends on illumination. Temperature can only vary current's value. So, absence of illuminations results zero current and voltage generation independent of what the temperature is. Amount of illumination is directly proportional to the value of generated current and voltage from PV panel. As the illumination increases with constant temperature both generated current and voltage of PV panel increases.
Temperature has different effect at the generated voltage and current. Temperature is inversely proportional to PV panel's generated voltage and directly proportional to current generated by PV panel. As the temperature increases PV panel's current will increase and voltage will decrease. If temperature decreases PV panel's current will decrease and voltage will increase.

3D graphical representation of PV cell/panel power with changing illumination and temperature at different loads is shown in Fig. 8.

TABLE 1. INPUT PERFORMANCE WITH LOAD

\begin{tabular}{|c|c|c|c|c|c|c|c|c|c|c|c|c|c|}
\hline \multirow{2}{*}{$\begin{array}{c}\mathrm{PV} \\
(\mathrm{W} / \mathrm{m} 2)\end{array}$} & \multirow{2}{*}{$\begin{array}{l}\text { Cell } \\
\left({ }^{\circ} \mathrm{C}\right)\end{array}$} & \multicolumn{3}{|c|}{ Load $=2.4 \Omega$} & \multicolumn{3}{|c|}{ Load $=5 \Omega$} & \multicolumn{3}{|c|}{ Load $=10 \Omega$} & \multicolumn{3}{|c|}{ Load $=100 \Omega$} \\
\hline & & $\begin{array}{c}\text { Input } \\
\text { Voltage } \\
(\mathrm{V})\end{array}$ & $\begin{array}{l}\text { Input } \\
\text { Current } \\
\text { (A) }\end{array}$ & $\begin{array}{l}\text { Input } \\
\text { Power } \\
\text { (W) }\end{array}$ & $\begin{array}{l}\text { Input } \\
\text { Voltage } \\
\text { (V) }\end{array}$ & $\begin{array}{l}\text { Input } \\
\text { Current } \\
\text { (A) }\end{array}$ & $\begin{array}{l}\text { Input } \\
\text { Power } \\
\text { (W) }\end{array}$ & $\begin{array}{c}\text { Input } \\
\text { Voltage } \\
\text { (V) }\end{array}$ & $\begin{array}{l}\text { Input } \\
\text { Current } \\
\text { (A) }\end{array}$ & $\begin{array}{l}\text { Input } \\
\text { Power } \\
\text { (W) }\end{array}$ & $\begin{array}{c}\text { Input } \\
\text { Voltage } \\
\text { (V) }\end{array}$ & $\begin{array}{l}\text { Input } \\
\text { Current } \\
\text { (A) }\end{array}$ & $\begin{array}{l}\text { Input } \\
\text { Power } \\
\text { (W) }\end{array}$ \\
\hline 0 & 0 & 0 & 0 & 0 & 0 & 0 & 0 & 0 & 0 & 0 & 0 & 0 & 0 \\
\hline 0 & 25 & 0 & 0 & 0 & 0 & 0 & 0 & 0 & 0 & 0 & 0 & 0 & 0 \\
\hline 250 & 25 & 235.04 & 95.94 & 22550.18 & 261.38 & 93.06 & 24322.81 & 260.50 & 93.27 & 24297.77 & 258.61 & 93.69 & 24229.51 \\
\hline 500 & 25 & 267.71 & 185.46 & 49649.16 & 266.62 & 186.03 & 49598.64 & 266.63 & 186.02 & 49598.83 & 263.15 & 187.54 & 49352.07 \\
\hline 750 & 25 & 269.56 & 278.23 & 74999.93 & 268.86 & 278.77 & 74950.24 & 268.71 & 278.88 & 74939.23 & 267.91 & 279.46 & 74870.32 \\
\hline 1000 & 25 & 271.26 & 369.77 & 100304.20 & 269.10 & 372.02 & 100111.12 & 269.96 & 371.17 & 100200.59 & 269.07 & 372.05 & 100107.77 \\
\hline 1000 & 50 & 246.86 & 375.68 & 92741.63 & 247.03 & 375.49 & 92756.42 & 246.04 & 376.60 & 92658.72 & 245.09 & 377.60 & 92545.11 \\
\hline 1000 & 0 & 293.70 & 365.71 & 107409.05 & 293.54 & 365.86 & 107394.89 & 293.27 & 366.11 & 107369.58 & 292.01 & 367.21 & 107229.25 \\
\hline
\end{tabular}

TABLE 2. INPUT-OUTPUT PERFORMANCE WITH LOAD

\begin{tabular}{|c|c|c|c|c|c|c|c|c|c|c|c|c|c|}
\hline \multirow[b]{2}{*}{$\begin{array}{c}\mathrm{PV} \\
(\mathrm{W} / \mathrm{m} 2)\end{array}$} & \multirow{2}{*}{$\begin{array}{l}\text { Cell } \\
\left({ }^{\circ} \mathrm{C}\right)\end{array}$} & \multicolumn{3}{|c|}{ Load $=2.4 \Omega$} & \multicolumn{3}{|c|}{ Load $=5 \Omega$} & \multicolumn{3}{|c|}{ Load $=10 \Omega$} & \multicolumn{3}{|c|}{ Load $=100 \Omega$} \\
\hline & & $\begin{array}{c}\text { Input } \\
\text { Voltage } \\
\text { (V) }\end{array}$ & $\begin{array}{c}\text { Output } \\
\text { Voltage } \\
\text { (V) }\end{array}$ & $\begin{array}{l}\text { Output } \\
\text { Current } \\
\text { (A) }\end{array}$ & $\begin{array}{c}\text { Input } \\
\text { Voltage } \\
\text { (V) }\end{array}$ & $\begin{array}{c}\text { Output } \\
\text { Voltage } \\
\text { (V) }\end{array}$ & $\begin{array}{l}\text { Output } \\
\text { Current } \\
\text { (A) }\end{array}$ & $\begin{array}{c}\text { Input } \\
\text { Voltage } \\
\text { (V) }\end{array}$ & $\begin{array}{c}\text { Output } \\
\text { Voltage } \\
\text { (V) }\end{array}$ & $\begin{array}{l}\text { Output } \\
\text { Current } \\
\text { (A) }\end{array}$ & $\begin{array}{l}\text { Input } \\
\text { Voltage } \\
\text { (V) }\end{array}$ & $\begin{array}{c}\text { Output } \\
\text { Voltage } \\
\text { (V) }\end{array}$ & $\begin{array}{c}\text { Output } \\
\text { Current } \\
\text { (A) }\end{array}$ \\
\hline 0 & 0 & 0 & 0 & 0 & 0 & 0 & 0 & 0 & 0 & 0 & 0 & 0 & 0 \\
\hline 0 & 25 & 0 & 0 & 0 & 0 & 0 & 0 & 0 & 0 & 0 & 0 & 0 & 0 \\
\hline 250 & 25 & 235.04 & 230.25 & 95.94 & 261.38 & 345.61 & 69.12 & 260.50 & 488.50 & 48.85 & 258.61 & 1542.42 & 15.42 \\
\hline 500 & 25 & 267.71 & 339.16 & 141.32 & 266.62 & 489.23 & 97.85 & 266.63 & 691.87 & 69.19 & 263.15 & 2181.59 & 21.82 \\
\hline 750 & 25 & 269.56 & 413.17 & 172.15 & 268.86 & 596.09 & 119.22 & 268.71 & 842.91 & 84.29 & 267.91 & 2663.93 & 26.64 \\
\hline 1000 & 25 & 271.26 & 473.63 & 197.34 & 269.10 & 682.61 & 136.52 & 269.96 & 965.98 & 96.60 & 269.07 & 3052.65 & 30.53 \\
\hline 1000 & 50 & 246.86 & 453.48 & 188.95 & 247.03 & 654.62 & 130.92 & 246.04 & 925.03 & 92.50 & 245.09 & 2922.60 & 29.23 \\
\hline 1000 & 0 & 293.70 & 491.66 & 204.86 & 293.54 & 709.59 & 141.92 & 293.27 & 1003.33 & 100.33 & 292.01 & 3169.97 & 31.70 \\
\hline
\end{tabular}


Talking about increase in efficiency of PV system. It is concluded that, hundred percent $(100 \%)$ efficiency is achieved in stability by removing oscillations and getting hundred percent (100\%) stable output from photovoltaic panel.

Now moving towards the tracking speed, the tracking speed of conventional PAO algorithm is low. But tracking speed of improved PAO is increased by reducing the number of perturbations to reach MPP. Number of perturbations are reduced by using "fix change in stepsize". Output voltage of PV panel at standard test condition $\left(1000 \mathrm{w} / \mathrm{m}^{2}\right.$ and $\left.25^{\circ} \mathrm{C}\right)$ using conventional PAO algorithm is shown in Fig. 9.

It can be clearly observed in Fig. 9 that voltage reach near the MPP at 0.25 seconds and then start oscillations of one volt around MPP. Comparing to this observing the output voltage of PV panel at standard test condition using improved or proposed PAO algorithm it is observed that voltage reach near the same MPP at 0.06 seconds and then start oscillations, after some oscillations which become smaller and smaller it attains the MPP in 0.35 seconds. The margin of improvement is 0.19 seconds.

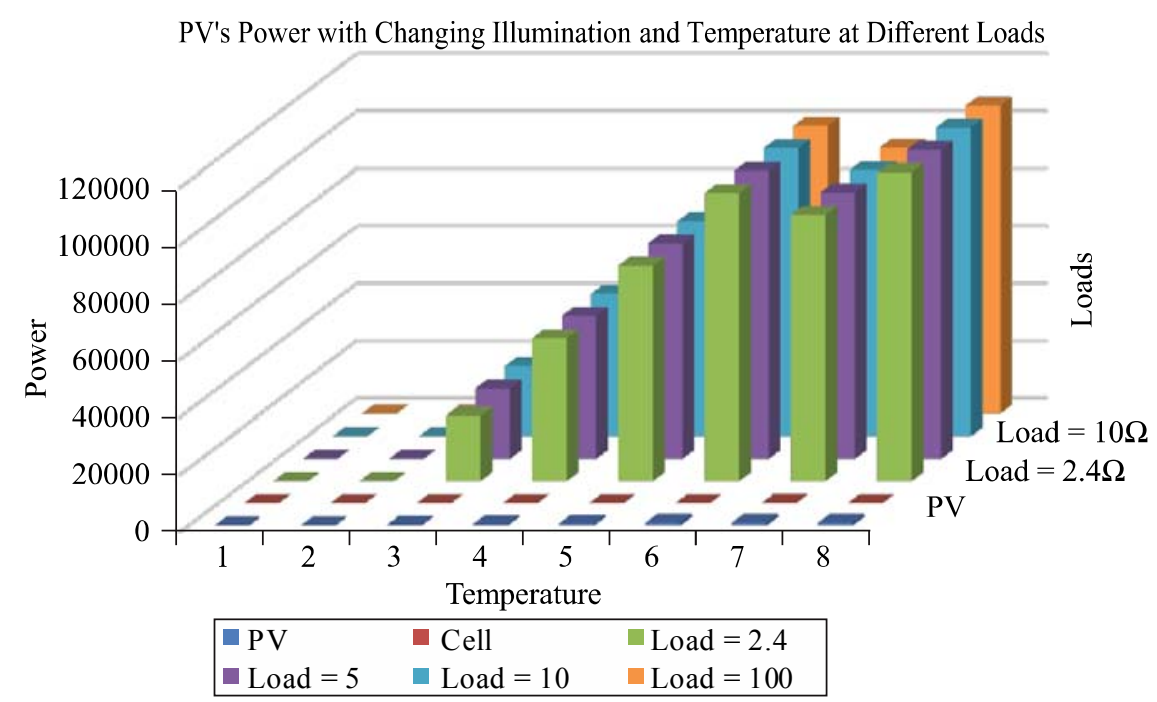

FIG. 8. PV'S POWER WITH CHANGING ILLUMINATION AND TEMPERATURE AT DIFFERENT LOADS

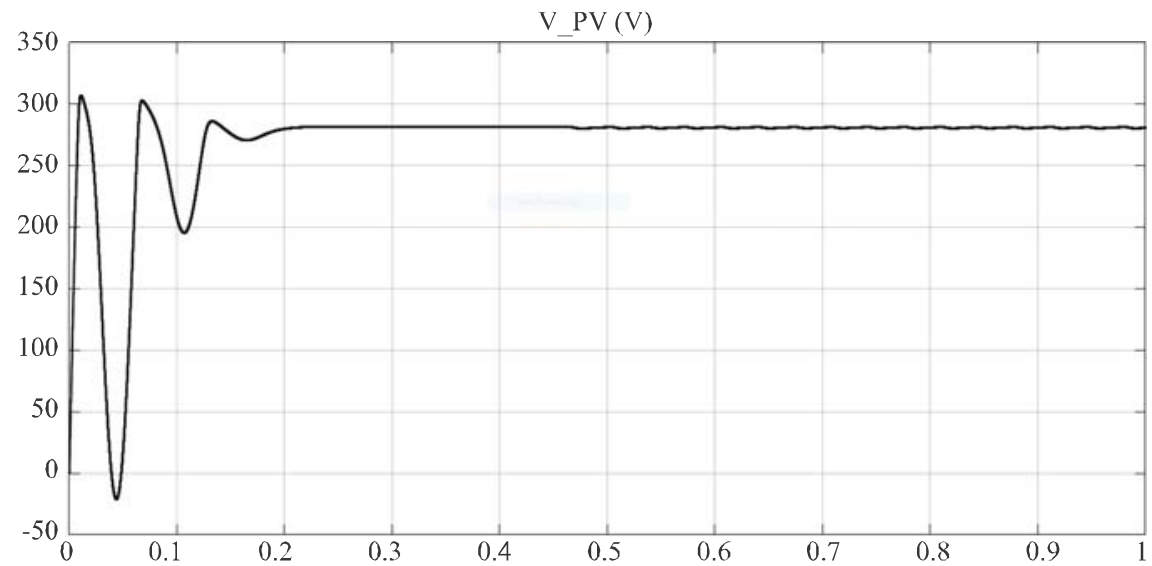

FIG. 9. O/P OF PV ARRAY WITH CONVENTIONAL PAO ALGORITHM AT STC $\left(1000 \mathrm{~W} / \mathrm{M}^{2}-25^{\circ} \mathrm{C}\right)$ 
The proposed PAO algorithm's MPP tracking is faster than conventional PAO algorithm by 0.19 seconds. It tracks MPP 0.19 seconds before old PAO algorithm at standard test condition.

Improvement in PAO algorithm to this level is achieved first time. So this is the novelty of this work.

\section{CONCLUSION}

In this paper, three main problems of PV array (oscillations, slow speed response and response during changing weather conditions) are tried to resolve. Two problems are solved (oscillations removed completely, response speed is increased by reducing the maximum possible number of perturbations to reach MPP) but limitation to speed of response is that tracking speed during continuously conditional change in weather conditions cannot be eliminated completely but to some extent (tracking speed reduces during the positive weather change if the perturbation process continues and the system does not reach the stability yet). Oscillation of operating point around MPP was a big problem in the efficiency of PV system which is removed by using "reduce and fix" strategy in PAO algorithm. Simulations performed in MATLAB/SIMULINK.

\section{ACKNOWLEDGMENTS}

The authors are graciously thankful Centre of Energy Research \& Development, University of Engineering \& Technology, Lahore, Pakistan, for approving this research. Authors further intend to carry on the response of photovoltaic system at continuously changing weather conditions to improve the efficiency by speeding up the tracking process. Tracking of maximum power point with single perturbation instead of using continuous perturbations to increase efficiency. And on the tracking of maximum power point without use of converters in order to reduce so the cost.

\section{REFERENCES}

[1] Jusoh, A., Sutikno, T., Guan, T.K., and Mekhilef, S., "A Review on Favorable Maximum Power Point Tracking Systems in Solar Energy Application", Telkomnika, Telecommunication Computing Electronics and Control, Volume 12, No. 1, pp. 6-22, 2014.

[2] Dong, J., Zhang, C.J., and Li, Y.B., "Comparison of Duty Ratio Perturbation and Observation and Reference Voltage Perturbation and Observation Methods Applied in MPPT", Conference on Power Electronics and Motion Control, Volume 2, No. 6, pp. 1358-1362, 2012.

[3] "French-German Collaborators Claim Solar Cell Efficiency World Record", EE Times Europe. 2 December, 2014. Retrieved 3 December, 2014.

[4] Sivaraman, P., and Nirmalkumar, A., "A New Method Of Maximum Power Point Tracking for Maximizing the Power Generation from an SPV Plant", Journal of Scientific and Industrial Research, Volume 74, No. 7, pp. 411-415, July, 2015.

[5] Sivagamasundari, M.S., Melba, M.P., and Velvizhi, V.K., "Maximum Power Point Tracking For Photovoltaic System by Perturb and Observe Method Using Buck Boost Converter", International Journal of Advanced Research in Electrical, Electronics and Instrumentation Engineering, Volume 2, Issue 6, June, 2013.

[6] Jusoh, A.B., Mohammed, O.J.E.I., and Sutikno, T., "Variable Step Size Perturb and Observe MPPT for PV Solar Applications", TELKOMNIKA, Volume 13, No. 1, pp. 1-12, March, 2015.

[7] Emilio, M., Giovanni, P., and Giovanni, S., "Two-Steps Algorithm Improving the PandO Steady State MPPT Efficiency", Applied Energy, Volume 113, pp. 414-421, January, 2014.

[8] Pallavee, B., and Nema, R.K., "Maximum Power Point Tracking Control Techniques", State of Art in PV Application", Renewable and Sustainable Energy Reviews, Volume 23, pp. 224-241, 2013.

[9] Ali, A.G., Seyed, M.S., and Asma, S., "A High Performance Maximum Power Point Tracker for PV Systems", International Journal of Electrical Power and Energy Systems, Volume 53, pp. 237-243, 2013. 
[10] Nasr Allah, A., Saied, M., Mustafa, M., and AbdelMoneim, T., "A Survey of Maximum PPT techniques of PV Systems", Energytech, IEEE Browse Conference Publications, pp. 1-17, 2012.

[11] Zegaoui1, A., Aillerie, M., Petit, P., Sawicki, J.P., Jaafar, A., Salame, C., and Charles, J.P., "Comparison of Two Common Maximum Power Point Trackers by Simulating of PV Generators", Energy Procedia, Volume 6, pp. 678-687, December, 2011.

[12] Adel, A., Elbaset, Ali, H., and Abd-El, M.S., “ A Modified Perturb and Observe Algorithm for Maximum Power Point Tracking of Photovoltaic System Using BuckBoost Converter", Volume 43, No. 3, pp. 344-362, May, 2015.

[13] Alsadi, S., and Alsayid, B., "Maximum Power Point Tracking Simulation for Photovoltaic Systems Using Perturb and Observe Algorithm”, International Journal of Engineering and Innovative Technology, Volume 2, Issue 6, December, 2012.

[14] Gomathy, S., Saravanan, S., and Thangavel, S., "Design and Implementation of Maximum Power Point Tracking (MPPT) Algorithm for a Standalone PV System", International Journal of Scientific and Engineering Research, Volume 3, Issue 3, pp. 3-4, March, 2012.
[15] Swathy, A., and Archana, R., "Maximum Power Point Tracking Using Modified Incremental Conductance for Solar Photovoltaic System”, International Journal of Engineering Innovative Technology, Volume 3, No. 2, pp. 333-337, 2013.

[16] Beydaghi, S., Vahidi, B., Ankouti, Y., and Gharehpetian, G.B., "Simulation of Improved Perturb and Observe MPPT Using SEPIC Converter", Science International, Volume 27, No. 3, pp. 1869-1873, Lahore, Pakistan, 2015.

[17] Santos, T.J.A., and Galhardo, A., "A Perturbation and Observation Routine Used to Control a Power Converter", $6^{\text {th }}$ World Congress on Nature and Biologically Inspired Computing, pp. 78-83, 2014.

[18] Ahmed, K.A., Ahmed, M.M., Shehab, A., and Prasad, N.E., "High-Performance Adaptive Perturb and Observe MPPT Technique for Photovoltaic-Based Microgrids", IEEE Transactions on Power Electronics, Volume 26, No. 4, pp. 1010-1021, 2011.

[19] Pradhan, S.K., and Das, D., "Modeling and Simulation of PV Array with Boost Converter: An Open Loop Study", Thesis, Department of Electrical Engineering, National Institute of Technology, pp. 50-51, Rourkela, India, 2011. 